\title{
THE EFFECT OF THE USE OF INDIGENOUS KNOWLEDGE-BASED PHYSICS COMICS OF ANDROID-BASED MARBLES GAMES ON VERBAL REPRESENTATION AND CRITICAL THINKING ABILITIES IN PHYSICS TEACHING
}

\author{
Almira Eka Damayanti iD, Heru Kuswanto iD \\ Universitas Negeri Yogyakarta (Indonesia) \\ almiraekad@gmail.com, herukus61@uny.ac.id
}

Received November 2020

Accepted June 2021

\section{Abstract}

This research aims to reveal the effectiveness of the use of an indigenous knowledge-based physics comic of Android-based marbles games on verbal representation and critical thinking abilities. It is a quasi-experiment applying the pretest-posttest control group design. The research sample consists of two classes: the control and experimental classes, each of which consists of 35 students established using the cluster random sampling technique. The effectiveness of the indigenous knowledge-based physics comic of marbles games was analyzed using the quantitative method applying the effect size analysis. The result of the effect size analysis obtained from Cohen's $\mathrm{f}$ in verbal representation ability is 0.11 interpreted as medium effect size and critical thinking ability is 0.43 interpreted as large effect size. This shows that the developed indigenous knowledge-based physics comic of Android-based marbles games in physics teaching gives effects to verbal representation and critical thinking abilities of the students. In other words, the developed comic is effective in improving verbal representation and critical thinking abilities.

Keywords - Android, Critical thinking, Indigenous knowledge, Physics comic, Verbal representation.

\section{To cite this article:}

Damayanti, A.E., \& Kuswanto, H. (2021). The effect of the use of indigenous knowledge-based physics comics of android-based marbles games on verbal representation and critical thinking abilities in physics teaching. Journal of Technology and Science Education, 11(2), 581-593. https:/ / doi.org/10.3926/jotse.1142

\section{Introduction}

The goal of global education is that the 21 st Century teaching has to cover the learning skill and innovation aspects. The skill that needs to be developed is higher order thinking skill, one of which is critical thinking ability (Wartono, Hudha \& Batlolona, 2017). Developing critical thinking ability helps students understand the information conveyed in teaching. Critical thinking is a well-oriented and obvious process to analyze, evaluate, and synthesize students' thought and believes (Demirci, 2017; Diana \& Djamas, 2017). However, students' critical thinking ability is still low and thus needs improvement (Puspita, Kaniawati \& Suwarma, 2017). The improvement can be made by integrating the indicators of critical thinking ability in teaching (Handayani, Jumadi, Wilujeng \& Kuswanto, 2019; Prayogi, Yuanita \& Wasis, 2018). Critical thinking indicators according to Ennis (1993) are capable of: (1) formulating the 
main problem; (2) disclose facts; (3) select the logical argument; (4) detect bias with different viewpoints; (5) draw conclusions.

The school curriculum in Indonesia also has the same goal as that of the 21st Century teaching, particularly for the teaching of physics in senior high school, whose goal is to develop the ability to analyze and apply, as well as modify or design physics concepts ("Standar Kompetensi Dan Kompetensi Dasar Mata Pelajaran Fisika Untuk SMA Dan MA", Badan Standar Nasional Pendidikan, 2016). In reality the students look passive with the traditional lecture-format teaching. Therefore, there needs to be innovation of a teaching process which can involve students directly in teaching. The innovation in teaching is very important in order to support and train problem solving ability. One of the forms of the exercises in problem solving ability can be done through representation ability (Docktor \& Mestre, 2014).

Physics representation is related to four representations: verbal representation, figure or diagram, mathematical and symbolic, and graphs (De Cock, 2012; Selamet, Mahardika \& Supriadi, 2018). A specific physics description can be achieved by describing physics concepts (Madrid, Leon-Mantero \& Maz-Machado, 2015) through verbal representation. In general, in school examinations the students solve only low cognitive level problems, such as defining, memorizing, and solving problems through mathematical equations (Istiyono, 2017). Students' verbal representation ability is important to improve in physics teaching.

Teaching processes will be effective and efficient if supporting media are available. Interesting supporting media will encourage students to do individual activities. One of those media is comic instructional media (Ntobuo, Arbie \& Amali, 2018). The development in life in recent years has had a profound impact on the market of entertainment media, because it is affected by the high production value of animation, comics, and games (Sheu \& Chu, 2017). The current development of science makes comics not only as entertainment but also as educational media (Haroky, Nikmah, Wilujeng, Jumadi \& Kuswanto, 2019). Comics are a medium which is widely known by youngsters; this allows stories to be read and understood relatively quickly and can give students the information they need in the targeted way (Egusa, Funaoi, Daikoku, Inai, Kusunoki, Takenaka et al., 2014). Nowadays, handheld communication media or more widely known as gadgets become the thing most demanded by Indonesian people (Marhadini, Akhlis \& Sumpono, 2017). Therefore, printed comics can be packaged in the form of digital or Android comic for teaching in line with the advancement in technology.

Digital comics are developing in the society, and therefore many people use them. Comics can be written on paper, but they can also be made by using the Internet and even be mixed with digital technology (Priyadi, Kuswanto \& Sumarna, 2020). Being in the Android form facilitates students to carry them everywhere. Android comics are also paperless, and they contain not only learning materials but also animation, teaching video, and a great number of test items (Hadi \& Dwijananti, 2015). Digital comics can create a more meaningful learning environment, where the materials taught are directly related to students' lives. In addition, the students can participate actively in teaching-learning processes. Comics can be more contextual if they integrate local wisdom/indigenous knowledge.

The learning activities which are related to indigenous knowledge can make students more motivated (Liliarti \& Kuswanto, 2018). However, local people who still adhere to traditional values are ignored in the field of education, including in physics teaching (Wati, Hartini, Hikmah \& Mahtari, 2018). One kind of indigenous knowledge which can be integrated in physics teaching is games. Traditional games themselves can be a real example which is contextual in teaching activities (Liu, Shaikh \& Gazizova, 2020). Physics concepts that can be integrated with indigenous knowledge such as marble game have not been used to explain physics materials as a whole but as an example. When students are motivated to learn, they will participate actively in teaching-learning processes (Saregar, 2016). Therefore, teaching will be focused on students, which is the goal of Curriculum 2013 (Fadilah \& Suparwoto, 2016).

Based on the consideration of the facts that have been explained, it is important to conduct research in the form of an innovative learning media, namely the Android-based marble game comic which is 
effective in increasing critical thinking skills and verbal representation of high school students on impulse momentum material. Verbal representation and critical thinking abilities will be easily improved if a medium has advantages such as attractiveness and it can make students enjoy reading. The use of Android comics is expected to be able to improve students' verbal representation and critical thinking abilities in physics teaching.

\section{Literature Review}

\subsection{Android-Based Instructional Media}

The use of instructional media in teaching processes can generate interest, motivation, and stimuli in teaching processes, and they can even give psychological impact to students (Sapriyah, 2019). Cellular instructional media with mobile learning can provide instruction which can be accessed by the community at large (Shabrina, Warsono \& Kuswanto, 2017). Learning through the use of cellular application can help students achieve the instructional objectives (Chen, Sivo, Seilhamer, Sugar \& Mao, 2013). It can give a positive impact to the its utility and user's attitude toward the intention to use mobile learning. The development of m-learning needs a design which is suitable with the learning situation and students' condition (Husna \& Kuswanto, 2018).

The life of modern society currently is not separated from smartphones, one of the smartphone users is a student. According to Chu (2014) technological developments do not seem to only bring profit. When educators explain material in class, students are often busy playing with smartphones, which indicates that students are addicted to smartphones (Yalda, Michikyan \& Morris, 2014). Aljomaa, Al.Qudah, Albursan, Bakhiet and Abduljabbar (2016) mention Intoverted individuals usually rely on smartphone usage, smartphone social apps, and social media found on smartphones (Kim, Chung, Jang \& Chung, 2017) that smartphone addiction can happen because people enjoy using smartphones too much.

Smartphone addiction can be used in education, where smartphone innovation in education can be used well in teaching. The Android is the system mostly used in the society. It is the system platform in smartphones currently popular in the society (Damayanti, Syafei, Komikesari \& Rahayu, 2018).

\subsection{Indigenous Knowledge: Marbles Game}

Indigenous knowledge or often referred to as local wisdom is the tradition that has become the characteristic of a region, which is developed from that region (Sudirman, Mellawaty, Yaniwati \& Indrawan, 2020). Husna and Kuswanto (2018) states that indigenous knowledge is the knowledge that has been developing for a long time and it becomes the characteristic of a community or certain culture. One of the examples of indigenous knowledge is traditional games. Traditional games are entertaining activities using simple instruments inherited from generation to generation. They take various forms and types, one of which is marbles game, which is a very popular game in the society. They are called with various names in accordance with the place of origin, including gundu, tale, neyker, setein, pincian, and so forth (Febriyanti, Kencanawaty \& Irawan, 2019). Marbles are round like small balls made of cement and chalk. They are $1.25 \mathrm{~cm}$ in diameter and weigh about 10 grams. Besides, usually they are ornamented with colours, like those in the picture below.

Playground marbles usually required field and draw a circle on the ground or asphalt as a place to collect marbles results of each pair of participant game. The more the number of marbles collected, the bigger the circle, but the less the number of marbles collected, the smaller the circle used in the marbles game.

Stages of preparation in the game of marbles, among others: (1) The game usually involves 3-5 children or even more, (2) set up a five-point marbles for each child or dependent on the agreement of the players, (3) of sandy soil on the playground or a rather flat, non-declining field.

Batiste (2002) points out that indigenous knowledge in education is a developing field of research, nationally and internationally, especially for those who are interested in educational innovation. The educational system can combine indigenous knowledge and modern education so as to optimize cognitive competence (Pierotti, 2011). 


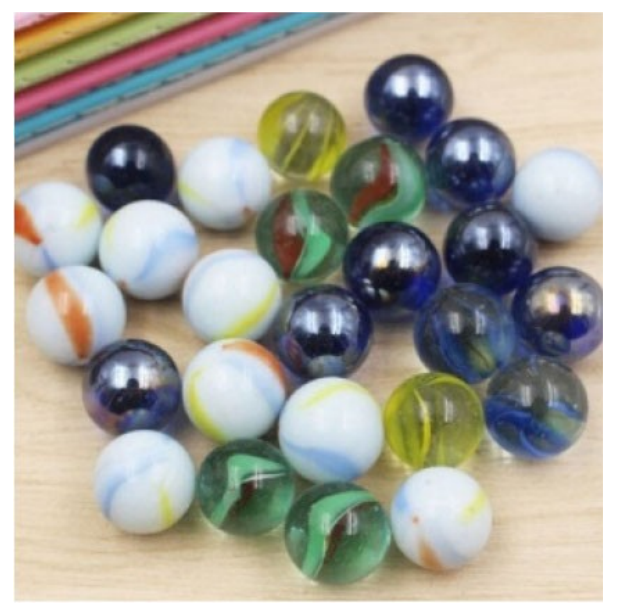

Figure 1. Marbles

\subsection{Physics Concepts in Marbles Game}

Physics is close to everyday events and phenomena. Good physics instruction must be done by identifying physical symptoms surrounding the students. Indigenous knowledge can become an effort to see physics phenomena which are close to the custom/tradition of a certain region. The physics materials stated in the indigenous knowledge-based physics comic media of Android-based marbles game are momentum and impulse in marble game, including all measured indicators, i.e. critical thinking and verbal representation abilities. Table 1 presents the analysis of the physics aspects in indigenous knowledge of marbles game.

Learning media in the form of physics comics based on indigenous knowledge on marbles games is a means of learning physics. This media can make physics learning simpler where the learning applies the values of the marble game. This medium is used as a physics instructional medium to create a contextual instruction.

\begin{tabular}{|c|c|c|}
\hline Variable & Indicator & Treatment Given in Comics \\
\hline & $\begin{array}{l}\text { Understanding } \\
\text { concept, principle, } \\
\text { and solving problems } \\
\text { by writing in words }\end{array}$ & $\begin{array}{l}\text { - The concept of impulse in marble games when marbles are flicked is } \\
\text { explained in the form of pictures. } \\
\text { - A momentum phenomenon in marble games played by two players } \\
\text { using different size marbles is presented. } \\
\text { - A picture of marbles from flicking to movement is presented as a form } \\
\text { of understanding of the concept of the relationship between } \\
\text { momentum and impulse. } \\
\text { - A picture of collisions among marbles is presented as a form of } \\
\text { understanding concepts, principles, and solving problems of the } \\
\text { characteristics of the collision. }\end{array}$ \\
\hline $\begin{array}{l}\text { Verbal } \\
\text { representation }\end{array}$ & $\begin{array}{l}\text { Students can explain } \\
\text { verbally through data } \\
\text { such as pictures, } \\
\text { symbols, mathematics } \\
\text { which are presented. }\end{array}$ & $\begin{array}{l}\text { - An explanation and similarities about the concept of impulse in marbles } \\
\text { - The is presented } \\
\text { verbally } \\
\text { - The magnitude of the relationship between the velocity of the marble } \\
\text { and the time of contact of the finger with the marble when the marble } \\
\text { starts to be flicked is presented. } \\
\text { - The quantities at the velocity of the initial and final momentum of } \\
\text { before and after the marble collides with another marble that exits the } \\
\text { circle or remains in the circle are presented in order to explain verbally } \\
\text { the concept of the momentum eternity law. } \\
\text { - A phenomenon of marbles colliding with other marbles or other } \\
\text { objects is presented as a result of the magnitude of the collision and the } \\
\text { characteristics of the collision is explained verbally. }\end{array}$ \\
\hline
\end{tabular}




\begin{tabular}{|c|c|c|}
\hline Variable & Indicator & Treatment Given in Comics \\
\hline \multirow{4}{*}{$\begin{array}{l}\text { Critical } \\
\text { thinking }\end{array}$} & Analyzing facts & $\begin{array}{l}\text { - A picture of a person flicking a marble from the rest position to moving } \\
\text { position is presented. } \\
\text { - A picture of children playing moving marbles is presented. } \\
\text { - A picture of a marble colliding with another marble is presented }\end{array}$ \\
\hline & $\begin{array}{l}\text { Formulating } \\
\text { problems }\end{array}$ & $\begin{array}{l}\text { - The magnitude of the impulse generated from the flicking force by the } \\
\text { flicker at short intervals when the marble is flicked is presented. } \\
\text { - The amount of momentum generated from different mass but the same } \\
\text { velocity when the marble moves is presented. } \\
\text { - The characteristics of the phenomenon when a marble is colliding with } \\
\text { another marble is presented. }\end{array}$ \\
\hline & $\begin{array}{l}\text { Defending, selecting, } \\
\text { clarifying and } \\
\text { evaluating logical } \\
\text { arguments }\end{array}$ & $\begin{array}{l}\text { - An explanation of what causes the magnitude of the force produced by } \\
\text { the flickers to vary is presented } \\
\text { - An explanation of what causes the velocity of marbles to vary is } \\
\text { presented. } \\
\text { - An explanation of what makes the momentum before and after a } \\
\text { collision is the same is presented. }\end{array}$ \\
\hline & Drawing conclusions & $\begin{array}{l}\text { - An explanation of the conclusion of the magnitude of the force } \\
\text { generated based on the concept of impulse is presented. } \\
\text { - An explanation of the conclusion of the magnitude of the force } \\
\text { generated based on the concept of momentum is presented. } \\
\text { - An explanation of the conclusion of the types of collisions based on } \\
\text { their characteristics is presented. }\end{array}$ \\
\hline
\end{tabular}

Table 1. Analysis of physics aspects of indigenous knowledge of marbles game

\section{Research Method}

\subsection{Method}

His research uses the quasi-experimental model with the pretest-posttest control group design. Table 2 shows the research design, where $\mathrm{O}_{1}$ is the pretest; $\mathrm{X}$ is the treatment; and $\mathrm{O}_{2}$ is the posttest.

\begin{tabular}{|l|c|c|c|}
\hline \multicolumn{1}{|c|}{ Group } & Pretest & Treatment & Posttest \\
\hline Control Class & $\mathrm{O}_{1}$ & $\mathrm{X}_{1}$ & $\mathrm{O}_{2}$ \\
\hline Experimental Class & $\mathrm{O}_{1}$ & $\mathrm{X}_{2}$ & $\mathrm{O}_{2}$ \\
\hline
\end{tabular}

Notes: $\mathrm{O}_{1}$ is pretest before treatment, $\mathrm{O}_{2}$ is posttest after treatment, $\mathrm{X}_{1}$ is Physics instruction through conventional teaching using power points, and $\mathrm{X}_{2}$ is Physics instruction Android-based marbles games comic.

Table 2. Research design

\subsection{Variables}

The variables in this research include the independent variable in the form of an Android-based marbles game comic and the dependent variable in the form of verbal representation and critical thinking abilities.

\subsection{Population and Sample}

The research population is grade X science students of State Senior High School (SSHS) 1 Kasihan, Bantul in the academic year 2019/2020. The sample consists of two classes - the control class and experimental class - each consisting of 35 students with the number of male learners as many as 15 people and women as many as 20 people. Grade X Science 1 students are the experimental class given treatment using an Android-based marbles game comic, while grade X Science 2 students are the control class. The try out sample was established using the cluster random sampling technique and thus their ability varies. 


\subsection{Data Analysis}

The research instrument is in the form of an essay test. Essay test used consist of 8 questions, where 4 questions are made based on verbal representation indicators and 4 questions are made based on critical thinking indicators. The test was used to collect the data on the students' verbal representation and critical thinking abilities. The data on the students' verbal representation and critical thinking abilities were analyzed using the Two Group Multivariate Analysis of Variant (MANOVA) to reveal the differences in the improvement of the verbal representation and critical thinking abilities of the students in the experimental and control classes.

The effectiveness of the indigenous knowledge-based physics comic of marbles game was analyzed using the quantitative method applying the effect size analysis. The effect size was obtained by calculating the value of Cohen's $f$ from the transformed scores of eta square $\left(\eta^{2}\right)$ in the table of the test between-subject effects or the value of Cohen's, which can be measured by using the following equation:

$$
f=\sqrt{\frac{\eta^{2}}{1-\eta^{2}}}
$$

The category of Cohen's $f$ can be stated in Table 3 .

\begin{tabular}{|c|c|}
\hline Cohen's f & Interpretation of Effect Size \\
\hline $0.00-0.10$ & Small Effect Size \\
\hline $0.11-0.25$ & Medium \\
\hline $0.26-0.40$ & Large \\
\hline
\end{tabular}

Table 3. Cohen's $f$ interpretation (Cohen, 1998)

\section{Findings and Discussion}

\subsection{Instructional Media}

The making of the media was done by making the scenario, characters, and roles. The comic was made in accordance with the indigenous knowledge of marbles games which contain characterization, characteristics of the characters, plot of story, dialogues, picture illustration, problems, and solution. The story in the comic was composed of eight episodes, each of which presents the sub-topic of momentum-impulse materials. The comic media was developed by using the Kodular program and the final product is in the form of apk which can be used both offline and online in playing the apperception (in the form of a video application of momentum-impulse material in everyday life) video in the Android-based comic. This comic medium of marbles game can be displayed by using a smartphone with the Android platform. The display of the comic media can be seen in Figure 2.

Figure 2 is a display of the developed comic media. The menu feature is the initial section of the media which contains an introduction, history, topics, knowledge, comics and about the developer. The preliminary feature discusses the competencies to be achieved in learning. The historical feature consists of a brief history of marble games, marbles game procedures, and a short video about playing marbles. The topic feature consists of 7 topics, where for the first meeting using topics 1 to 4 and the second meeting using topics 5 to 7 . The comic feature consists of 8 episodes where the comic content discusses impulse momentum material associated with marble games. Developer feature contains physics comic media developer biographies. The comics that have been made are then used in the teaching and learning process. Before starting the lesson, students were asked to install the marbles game comic on each of their androids. Once installed, the teacher explains the procedure for using the comic. The comic will be used for 2 meetings in the impulse momentum chapter. 

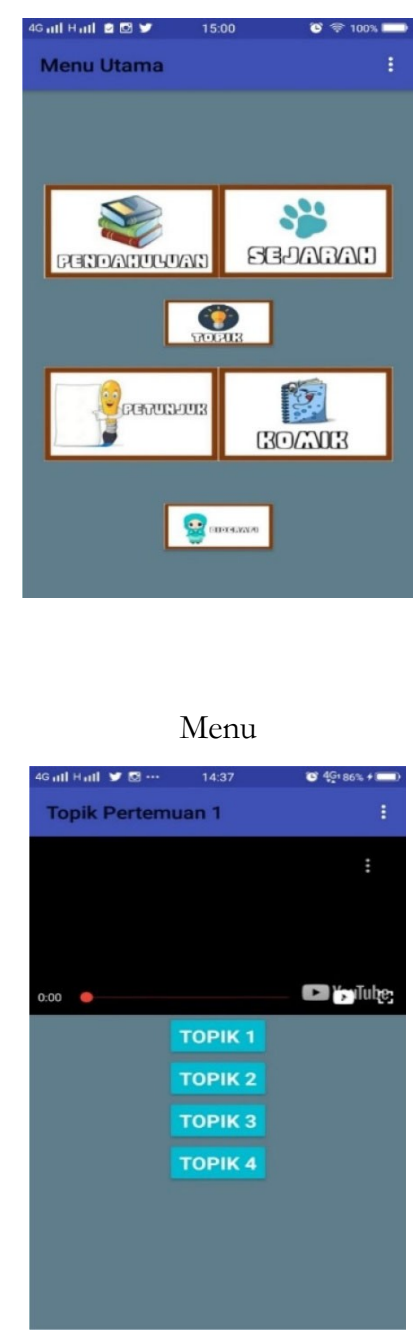

Topic feature
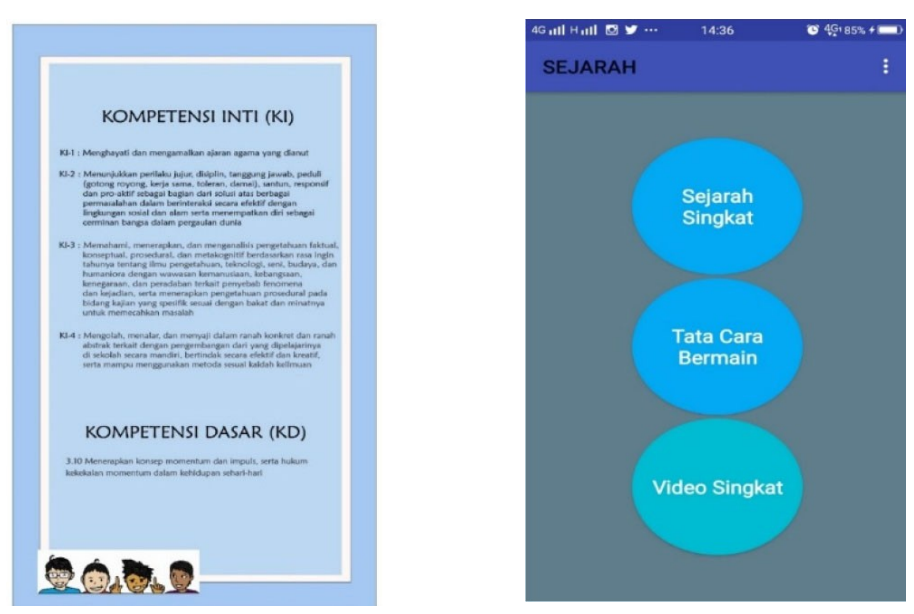

Introductory feature

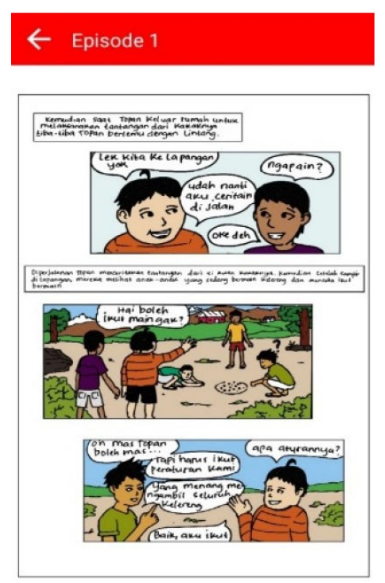

Comic feature
Historical feature

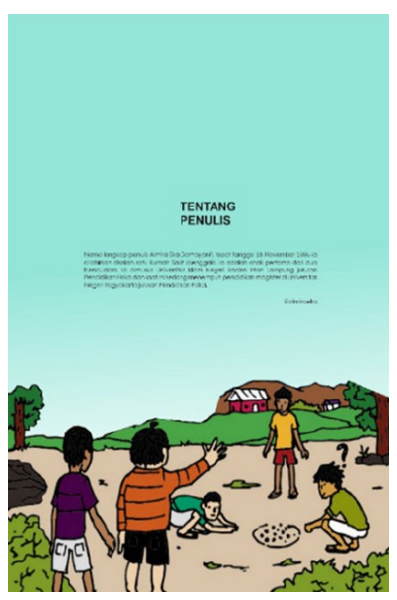

Development feature

Figure 2. Comic media display

\subsection{Statistical Tests}

In this research, the statistical test was conducted by using the multivariate statistical test or MANOVA. It was conducted in order to reveal the effectness of indigenous knowledge-based physics comic of Android-based marbles games in improving verbal representation and critical thinking abilities in physics instruction. The MANOVA analysis used the software of IBM SPSS Statistics 21. The requirements for the MANOVA analysis are when the test requirement is fulfilled, as follows.

1. The research has two or more dependent variables, i.e. verbal representation ability and critical thinking ability.

2. The independent variables in this research are the physics comic and indigenous knowledge media of marbles game.

3. The inter-class observation is independent; there is no relationship between the try out classes.

4. The sample used is more than 25 in each class.

5. There is no univariate or multivariate outliner.

6. Test of Normality

Whether or not the data were normally distributed was not seen in the data analysis of Shapiro-Wilk. The use of Shapiro-Wilk shows the value of Sig. in the Shapiro-Wilk column in the table of Tests of Normality in the SPSS output. Table 4 shows the result of the test of normality of the data from the experimental class. 
The value of Sig. in the Shapiro-Wilk column results in the conclusion that in the pretest and posttest, critical thinking has the values of sig. 0.68 and 0.061 which are lower than 0.05 and thus H_o is accepted, so that the distribution of the data on critical thinking is multivariately normal. The pretest and posttest scores in verbal representation are 0.65 and 0.067 which are lower than 0.05 and thus H_o is accepted, so that the distribution of the data on verbal representation is multivariately normal.

The value of Sig. in the Shapiro-Wilk column results in the conclusion that in the pretest and posttest critical thinking has the values of sig. 0.63 and 0.066 which are lower than 0.05 and thus H_o is accepted, so that the distribution of the data on critical thinking is multivariately normal. The pretest and posttest scores in verbal representation are 0.431 and 0.182 which are lower than 0.05 and thus H_o is accepted, so that the distribution of the data on verbal representation is multivariately normal.

\begin{tabular}{|l|l|r|r|r|r|r|r|}
\hline \multicolumn{2}{|c|}{ Group } & \multicolumn{2}{c|}{ Kolmogorov-Smirnov } & \multicolumn{3}{c|}{ Shapiro-Wilk } \\
\cline { 3 - 8 } \multicolumn{2}{|c|}{} & Statistic & \multicolumn{1}{c|}{ df } & \multicolumn{1}{c|}{ Sig. } & \multicolumn{1}{c|}{ Statistic } & \multicolumn{1}{c|}{ df } & \multicolumn{1}{c|}{ Sig. } \\
\hline \multirow{2}{*}{ Pretest } & Critical thinking & .171 & 35 & .011 & .943 & 35 & .068 \\
\cline { 2 - 8 } & Verbal representation & .173 & 35 & .009 & .942 & 35 & .065 \\
\hline \multirow{2}{*}{ Posttest } & Critical thinking & .163 & 35 & .020 & .941 & 35 & .061 \\
\cline { 2 - 8 } & Verbal representation & .142 & 35 & .071 & .942 & 35 & .067 \\
\hline
\end{tabular}

Table 4. Result of normality test of the experimental class

\begin{tabular}{|c|c|c|c|c|c|c|c|}
\hline \multirow{2}{*}{\multicolumn{2}{|c|}{ Group }} & \multicolumn{3}{|c|}{ Kolmogorov-Smirnov } & \multicolumn{3}{|c|}{ Shapiro-Wilk } \\
\hline & & \multirow{2}{*}{$\begin{array}{r}\text { Statistic } \\
.205\end{array}$} & \multirow{2}{*}{$\begin{array}{r}\text { df } \\
35\end{array}$} & \multirow{2}{*}{$\begin{aligned} \text { Sig. } \\
.001 \\
\end{aligned}$} & \multirow{2}{*}{$\begin{array}{r}\text { Statistic } \\
.942\end{array}$} & \multirow{2}{*}{\begin{tabular}{|r|} 
df \\
35 \\
\end{tabular}} & \multirow{2}{*}{$\begin{array}{r}\text { Sig. } \\
.063\end{array}$} \\
\hline Pretect & Critical thinking & & & & & & \\
\hline Fetest & Verbal representation & .123 & 35 & .198 & .970 & 35 & .431 \\
\hline \multirow{2}{*}{ Posttest } & Critical thinking & .141 & 35 & .075 & .942 & 35 & .066 \\
\hline & Verbal representation & .179 & 35 & .006 & .957 & 35 & .182 \\
\hline
\end{tabular}

Table 5. Result of normality test of the control class

\subsection{Test of Homogeneity}

The data analysis of the test of homogeneity was conducted by using the software of IBM SPSS Statistics 21. The homogeneity test is based on the variant-covariant similarity. The result of the analysis is presented in Table 6.

Based on the result of SPSS in Box's M table above, the value of Sig. is 0.393 which is bigger than 0.05 which means $\mathrm{H}_{0}$ is accepted, and thus the sample variation is homogeneous or relatively the same.

\begin{tabular}{|c|c|}
\hline Box's Test of Equality of Covariance Matrices* \\
\hline Box's M & 3.087 \\
\hline F & .996 \\
\hline df1 & 3 \\
\hline df2 & 832320.000 \\
\hline Sig. & .393 \\
\hline
\end{tabular}

Table 6. Result of homogeneity test

\subsection{MANOVA Test}

The MANOVA test was administered in order to see the average difference in the improvement of the verbal representation and critical thinking abilities of the students in the experimental and control classes. The analysis of the data on the MANOVA test was done by using the software of IBM SPSS Statistics 21 . The result of the MANOVA test is presented in Table 7. 
Based on the table above, for Group (critical thinking and verbal representation) with the type of Hotelling's Trace is obtained the value of Sig. 0.00 , which is lower than 0.05 and thus $\mathrm{H}_{0}$ is rejected. This shows that there is a difference in verbal representation and critical thinking abilities of the students taught by using the media usually used in physics instruction.

\begin{tabular}{|c|r|r|}
\hline Effect & Value & Sig. \\
\hline Hotelling's Trace & .783 & .000 \\
\hline
\end{tabular}

Table 7. Result of MANOVA test

\subsection{Analysis of Effect Size}

The effect size analysis was done to find out the effect size of indigenous knowledge-based physics comic of Android-based marbles games on the improvement of verbal representation and critical thinking abilities in physics instruction. The effect size is obtained by calculating the Cohen's $f$ value from the transformation of the beta square value in the test between-subject effects table when performing Hotteling's Trace analysis. The result of Cohen's $f$ calculation can be seen in Table 8.

\begin{tabular}{|c|l|r|r|}
\hline No & \multicolumn{1}{|c|}{ Variable } & Eta Square & Cohen's f \\
\hline 1 & Verbal representation & .104 & .11 \\
\hline 2 & Critical thinking & .395 & .43 \\
\hline
\end{tabular}

Table 8. Result of effect size estimation

Table 8 shows that the value of Cohen's $\mathrm{f}$ in verbal representation ability is 0.11 , interpreted as medium effect size. The value of Cohen's $f$ for critical thinking ability is 0.43 , interpreted as large effect size. The conclusion drawn from the above calculation is that the developed product in the form of an indigenous knowledge-based physics comic of Android-based marbles games in physics teaching has effects on students' verbal representation and critical thinking abilities. In other words, the developed product is effective in improving verbal representation and critical thinking abilities.

The finding above is supported by the statement that the use of interesting instructional materials with the character integrated in a comic makes students interested to learn (Fahri \& Samsudin, 2012; Saleh \& Alias, 2007). The teaching which uses comic media can improve students' understanding (Rahayu \& Kuswanto, 2020). Previous studies also reveal that science comics become an instrument to facilitate the teaching of natural science to students in an interesting way. Fatimah and Widiyarmoko (2014) emphasizes that science comics can improve students' critical thinking ability.

The aforedisplayed finding of this research states that the Android-based physics comic is feasible to use in physics instruction. This statement is supported by previous research (Hadi \& Dwijananti, 2015; Sari, Ratnaningtyas, Wilujeng, Jumadi \& Kuswanto, 2019) stating that an Android-based physics comic medium is feasible as a supplementary learning material for students. The use of mobile learning in teaching can improve a high learning achievement and it can be a medium to support teaching. A study by Hung, Hwang, Lin, Wu and Su (2013) reported the use of mobile learning-based inquiry approach in teaching, where the students learning by using the mobile learning-based inquiry approach has less cognitive load and higher learning achievement compared to those using the traditional approach.

The comic medium was developed by the physics analysis of the indigenous knowledge of marbles game on the ability of verbal representation and critical thinking. It was developed based on facts, concept of principle law, and theories in physics, especially momentum and impulse materials. This comic is used for high school students at the vulnerable age of 15-18 years. It invites students to understand the phenomena of momentum and impulse in everyday life. The phenomena given in the comic prove that the comic media can improve verbal representation and critical thinking abilities in a high category. This is in line with the 
research conducted by (Pramadi, Suastra \& Candiasa, 2013) who reported that the teaching by using a comic with local wisdom is better applied than teaching without using a comic containing local wisdom. Comics containing local wisdom can enrich scientific treasure and development of innovative education.

\section{Conclusion}

The use of indigenous knowledge-based physics comics: the Android-assisted marbles game in learning is more effective in improving critical thinking skills and verbal representation compared to learning using power points (PPT). Based on these findings, the effectiveness of comics can be seen from the results of the interpretation of medium effect size for verbal representation ability and large effect size for critical thinking ability. Physics comics packed with narration and story lines are integrated with marble games, making comics even more interesting. Through indigenous knowledge-based learning, it can also in still the value of local wisdom and easy learning of physics material. That is, learning media that links physics material with indigenous knowledge can make students better understand and maintain local wisdom. Therefore, physics comics based on indigenous knowledge: the Android-assisted marbles game can be used as an alternative in the selection of learning media to improve critical thinking skills and verbal representation.

\section{Declaration of Conflicting Interests}

The authors declared no potential conflicts of interest with respect to the research, authorship, and/or publication of this article.

\section{Funding}

The authors would like to express their sincere gratitude to the Ministry of Research and Technology and the National Research and Innovation Agency of the Republic Indonesia for funding this research through the Master Thesis Research Scheme (PTM) by contract number 058/SP2H/LT/DRPM/2020 and T/9.73/UN34.21/PT.01.03/2020 and the Institute for Research and Community Service (LPPM).

\section{References}

Aljomaa, S.S., Al.Qudah, M.F., Albursan, I.S., Bakhiet, S.F., \& Abduljabbar, A.S. (2016). Smartphone addiction among university students in the light of some variables. Computers in Human Behavior, 61, 155-164. https://doi.org/10.1016/j.chb.2016.03.041

Badan Standar Nasional Pendidikan (2016). Standar Kompetensi dan Kompetensi Dasar Mata Pelajaran Fisika untuk SMA dan $M A$. Jakarta: Depdiknas.

Batiste, M. (2002). Indigenous Knowledge and Pedagogy in First Nations Education: A Literature Review With Recommendations. National Working Group on Education and Ministry of Indian Affairs, INAC (Indian and Northern Affairs Canada). Ontario.

Chen, B., Sivo, S., Seilhamer, R., Sugar, A., \& Mao, J. (2013). User Acceptance of Mobile Technology: A Campus-Wide Implementation of Blackboard's MobileTM Learn Application. Journal of Educational Computing Research, 49(3), 327-343. https://doi.org/10.2190/EC.49.3.c

Chu, H.C. (2014). Potential negative effects of mobile learning on students' learning achievement and cognitive load-a format assessment perspective. Educational Technol-ogy \& Society, 17(1), 332-344. https://www.jstor.org/stable/jeductechsoci.17.1.332

Cohen, J. (1988). Statistical Power Analysis for the Behavioral Sciences (2nd ed.). L. Erlbaum Associates.

Damayanti, A.E., Syafei, I., Komikesari, H., \& Rahayu, R. (2018). Kelayakan Media Pembelajaran Fisika Berupa Buku Saku Android pada Materi Fluida Statis. Indonesian Journal of Science and Matematics Education, 1(1), 63-70. https://doi.org/10.24042/ijsme.v1i1.2476

De Cock, M. (2012). Representation Use And Strategy Choice In Physics Problem Solving. Physical Review Special Topics - Physics Education Research, 8(2), 020117. https://doi.org/10.1103/PhysRevSTPER.8.020117 
Demirci, F. (2017). The Effects of Using Concept Cartoons in Astronomy Subjects on Critical Thinking Skills among Seventh Grade Student. International Electronic Journal of Elementary Education, 10(2), 243-254. https://doi.org/10.26822/iejee.2017236119

Diana, S.P., \& Djamas, D. (2017). Pengembangan Perangkat Pembelajaran Fisika Berbasis Keterampilan Critical Thinking Dalam Problem-Based Learning. Jurnal Ilmiah Pendidikan Fisika Al-BiRuNi, 06(1), 125-135. https://doi.org/10.24042/jpifalbiruni.v6i1.648

Docktor, J.L., \& Mestre, J.P. (2014). Synthesis of discipline-based education research in physics. Physical Review Special Topics - Physics Education Research, 10(2), 020119. https://doi.org/10.1103/PhysRevSTPER.10.020119

Egusa, R., Funaoi, H., Daikoku, T., Inai, R., Kusunoki, F., Takenaka, M. et al. (2014). Improving the Usability of Manga-on-a-Tablet for Collaborative Learning. Proceedings of the 6th International Conference on Computer Supported Education (446-451). https://doi.org/10.5220/0004943404460451

Ennis, R.H. (1993). Critical Thinking Assessment. Theory into Practice, 32 (3), 179-186. https://doi.org/10.1080/00405849309543594

Fadilah, N.U., \& Suparwoto, S. (2016). Keterlaksanaan pembelajaran fisika implementasi kurikulum 2013 berdasarkan latar belakang akademik guru di MAN DIY. Jurnal Inovasi Pendidikan IPA, 2(1), 76. https://doi.org/10.21831/jipi.v2i1.8380

Fahri, H., \& Samsudin, K. (2012). Mobile Learning Environment System (MLES): The Case of Android-based Learning Application on Undergraduates' Learning. International Journal of Advanced Computer Science and Applications, 3(3). https://doi.org/10.14569/IJACSA.2012.030311

Fatimah, F., \& Widiyarmoko, A. (2014). Pengembangan Science Comic Berbasis Problem Based Learning Sebagai Media Pembelajaran pada Tema Bunyi dan Pendengaran untuk Siswa SMP. Jurnal Pendidikan IPA Indonesia, 3(2). https://doi.org/10.15294/jpii.v3i2.3114

Febriyanti, C., Kencanawaty, G., \& Irawan, A. (2019). Etnomatematika Permainan Kelereng. MaPan, 7(1), 32-40. https://doi.org/10.24252/mapan.2019v7n1a3

Hadi, W.S., \& Dwijananti, P. (2015). Pengembangan Komik Fisika Berbasis Android Sebagai Suplemen Pokok Bahasan Radioaktivitas Untuk Sekolah Menengah Atas. Unnes Physics Education Journal, 4(2).

Handayani, D.P., Jumadi, Wilujeng, I., \& Kuswanto, H. (2019). Development of Comic Integrated Student Worksheet to Improve Critical Thinking Ability in Microscope Material. Journal of Physics: Conference Series, 1233, 012069. https://doi.org/10.1088/1742-6596/1233/1/012069

Haroky, F., Nikmah, S., Wilujeng, I., Jumadi, \& Kuswanto, H. (2019). Android-Assisted Physics Comic Learning to Train Students' Conceptual Understanding of Newton's Gravity. Journal of Physics: Conference Series, 1233, 012045. https://doi.org/10.1088/1742-6596/1233/1/012045

Hung, P.H., Hwang, G.J., Lin, Y.F., Wu, T.H., \& Su, I.H. (2013). Seamless connection between learning and assessment- applying progressive learning tasks in mobile ecology inquiry. Educational Technology and Society, 16(1), 194-205.

Husna, M., \& Kuswanto, H. (2018). Development of Physics Mobile Learning Based on Local Wisdom to Improve Vector and Diagram Representation Abilities. International Journal of Interactive Mobile Technologies (IJIM), 12(6), 85. https://doi.org/10.3991/ijim.v12i6.8746

Istiyono, E. (2017). The analysis of senior high school students' physics HOTS in Bantul District measured using PhysReMChoTHOTS. AIP Conference Proceedings, 1868, 070008.

https://doi.org/10.1063/1.4995184

Kim, J., Chung, M.S., Jang, H.G., \& Chung, B.S. (2017). The use of educational comics in learning anatomy among multiple student groups. Anatomical Sciences Education, 10(1), 79-86.

https://doi.org/10.1002/ase.1619 
Liliarti, N., \& Kuswanto, H. (2018). Improving the Competence of Diagrammatic and Argumentative Representation in Physics through Android-based Mobile Learning Application. International Journal of Instruction, 11(3), 106-122. https://doi.org/10.12973/iji.2018.1138a

Liu, Z.Y., Shaikh, Z.A., \& Gazizova, F. (2020). Using the concept of game-based learning in education. International Journal of Emerging Technologies in Learning, 15(14), 53-64. https://doi.org/10.3991/ijet.v15i14.14675

Madrid, M.J., Leon-Mantero, C., \& Maz-Machado, A. (2015). Assessment of the Attitudes towards Mathematics of the Students for Teacher of Primary Education. OALib, 02(11), 1-8. https://doi.org/10.4236/oalib.1101936

Marhadini, S.A.K., Akhlis, I., \& Sumpono, I. (2017). Pengembangan Media Pembelajaran Berbasis Android pada Materi Gerak Parabola untuk Siswa SMA. Unnes Physics Education Journal, 6(3), 0-5.

Ntobuo, N.E., Arbie, A., \& Amali, L.N. (2018). The Development of Gravity Comic Learning Media Based on Gorontalo Culture. Jurnal Pendidikan IPA Indonesia, 7(2), 246-251.

https://doi.org/10.15294/jpii.v7i2.14344

Pierotti, R. (2011). Indigenous Knowledge, Ecology, and Evolutionary Biology. Routledge. https://doi.org/10.4324/9780203847114

Pramadi, I.P.W.Y., Suastra, I.W., \& Candiasa, I.M. (2013). Pengaruh Penggunaan Komik Berorientasi Kearifan Lokal Bali Terhadap Motivasi Belajar Dan Pemahaman Konsep Fisika. E-Journal Program Pascasarjana Universitas Pendidikan Ganesha, 3.

Prayogi, S., Yuanita, L., \& Wasis (2018). Critical-Inquiry-Based-Learning: Model of Learning to Promote Critical Thinking Ability of Pre-service Teachers. Journal of Physics: Conference Series, 947, 012013. https://doi.org/10.1088/1742-6596/947/1/012013

Priyadi, A.N.W., Kuswanto, H., \& Sumarna. (2020). Android physics comics to train the mathematical representation ability on momentum and impulse of senior high school students. Journal of Physics: Conference Series, 1440. 012041. https://doi.org/10.1088/1742-6596/1440/1/012041

Puspita, I., Kaniawati, I., \& Suwarma, I.R. (2017). Analysis of Critical Thinking Skills on The Topic of Static Fluid. Journal of Physics: Conference Series, 895, 012100. https://doi.org/10.1088/1742-6596/895/1/012100

Rahayu, M.S.I., \& Kuswanto, H. (2020). Development of android-based comics integrated with scientific approach in physics learning. Journal of Physics: Conference Series, 1440(1). https://doi.org/10.1088/1742-6596/1440/1/012040

Saleh, R., \& Alias, N.A. (2007). Letters to the Editor: Is actin the praziquantel receptor? International Journal of Antimicrobial Agents, 30(3), 280-281. https://doi.org/10.1016/j.ijantimicag.2007.05.004

Sapriyah. (2019). Media Pembelajaran Dalam Proses Belajar Mengajar. Prosiding Seminar Nasional Pendidikan FKIP, 2(1), 470-477.

Saregar, A. (2016). Pembelajaran Pengantar Fisika Kuantum dengan Memanfaatkan Media Phet Simulation dan LKM Melalui Pendekatan Saintifik: Dampak pada Minat dan Penguasaan Konsep Mahasiswa. Jurnal Ilmiah Pendidikan Fisika Al-Biruni, 5(1), 53. https://doi.org/10.24042/jpifalbiruni.v5i1.105

Sari, F.P., Ratnaningtyas, L., Wilujeng, I., Jumadi, \& Kuswanto, H. (2019). Development of Android Comics media on Thermodynamic Experiment to Map the Science Process Skill for Senior High School. Journal of Physics: Conference Series, 1233, 012052. https://doi.org/10.1088/1742-6596/1233/1/012052

Selamet, S., Mahardika, I.K., \& Supriadi, B. (2018). Analisis Verbal representation ability, Matematika, Gambar Dan Grafik (R-Vmgg) Siswa SMAN Pasirian Pada Materi Termodinamika. Seminar Nasional Pendidikan Fisika 2018, 3. 
Shabrina, S., Warsono, W., \& Kuswanto, H. (2017). Android Used in The Learning Innovation Atwood Machines on Lagrange Mechanics Methods. International Journal of Science and Applied Science: Conference Series, 2(1), 338. https://doi.org/10.20961/ijsascs.v2i1.16740

Sheu, J.J., \& Chu, K.T. (2017). Mining association rules between positive word-of-mouth on social network sites and consumer acceptance: A study for derivative product of animations, comics, and games.

Telematics and Informatics, 34(4), 22-33. https://doi.org/10.1016/j.tele.2016.12.010

Sudirman, Mellawaty, Yaniwati, R.P., \& Indrawan, R. (2020). Integrating local wisdom forms in augmented reality application: Impact attitudes, motivations and understanding of geometry of pre-service mathematics teachers'. International Journal of Interactive Mobile Technologies, 14(11), 91-106.

https://doi.org/10.3991/ijim.v14i11.12183

Sukma, T.A., Mundilarto, M., \& Putri, N.D. (2019). Local wisdom-Based Electronic Book on Newton's Law. Jurnal Ilmiah Pendidikan Fisika Al-Biruni, 8(2), 197-206. https://doi.org/10.24042/jipfalbiruni.v0i0.4368

Wartono, W., Hudha, M.N., \& Batlolona, J.R. (2017). How Are The Physics Critical Thinking Skills of The Students Taught by Using Inquiry-Discovery Through Empirical and Theorethical Overview? EURASLA Journal of Mathematics, Science and Technology Education, 14(2). https://doi.org/10.12973/ejmste/80632

Wati, M., Hartini, S., Hikmah, N., \& Mahtari, S. (2018). Developing physics learning media using 3D cartoon. Journal of Physics: Conference Series, 997, 012044. https://doi.org/10.1088/1742-6596/997/1/012044

Wiyono, K., Ismet, I., \& Saparini, S. (2020). Development of interactive multimedia for learning physics based on traditional games. Journal of Physics: Conference Series, 1480, 012074. https://doi.org/10.1088/1742-6596/1480/1/012074

Yalda, U.T., Michikyan, M., \& Morris, J. (2014). Five days at outdoor education camp without screens improves preteen skills with nonverbal emotion cues. Computers in Hu-man Behavior, 39 (2014) 387-392. https://doi.org/10.1016/j.chb.2014.05.036

Published by OmniaScience (www.omniascience.com) Journal of Technology and Science Education, 2021 (www.jotse.org)

\section{(c) (i) (3)}

Article's contents are provided on an Attribution-Non Commercial 4.0 Creative commons International License. Readers are allowed to copy, distribute and communicate article's contents, provided the author's and JOTSE journal's names are included. It must not be used for commercial purposes. To see the complete licence contents, please visit https://creativecommons.org/licenses/by-nc/4.0/. 